\title{
Ruminal degradation of Panicum grasses in three post-regrowth ages
}

\section{Degradabilidade ruminal de gramíneas do gênero Panicum em três idades de pós- rebrota}
Bruno Spindola Garcez ${ }^{* *}$ (D) , Arnaud Azevêdo Alves² (D), Ernando de Oliveira Macedo ${ }^{3}$ (D), Claudiane Morais dos Santos ${ }^{4}$ (D) , Daniel Louçana da Costa Araújo ${ }^{2}$ (D) Marlúcia da Silva Bezerra Lacerda ${ }^{5}$ (D)

\author{
'Instituto Federal do Ceará, Crateús, CE, Brazil. \\ ${ }^{2}$ Centro de Ciências Agrárias, Universidade Federal do Piauí, Teresina, PI, Brazil. \\ ${ }^{3}$ Instituto Federal do Piauí, Cocal, PI, Brazil. \\ ${ }^{4}$ Universidade Estadual do Piauí, Teresina, PI, Brazil. \\ Instituto Federal do Piauí, Teresina, Pl, Brazil. \\ *Correspondent - brunosgarcez@veterinario.med.br
}

\section{Section: Zootecnia \\ Received \\ November 1, 2018 \\ Accepted \\ January 28, 2020 \\ Published \\ May 16, 2020}

www.revistas.ufg.br/vet visit the website to get the how to cite in the article page.

\section{Abstract}

The objective was to evaluate the chemical composition and in situ degradation of Maasai, Mombasa and Tanzania grasses belonging to the genus Panicum, at 22,34 and 46 days after regrowth. The contents of dry matter (DM), crude protein (CP), neutral detergent fiber (NDF) and acid detergent fiber (ADF) were determined. For the evaluation of ruminal degradation, $4 \mathrm{~g}$ sample were placed in nylon bags and incubated in the rumen of a fistulated animal, for 6, 24 and $72 \mathrm{~h}$. The experiment had a completely randomized design for chemical composition analysis and a split-split plot completely randomized design for in situ degradation, with means compared by Tukey test at $5 \%$. There was an increase in the contents of DM $(+1.69 \%)$ and NDF $(+5.06 \%)(P<0.05)$ of the grasses at the highest cutting ages with reduction in the CP fraction. The potential degradation (PD) of DM, NDF and CP decreased with advancing age of grasses, with an increase in colonization time $(0.69 \mathrm{~h})$ and NDF degradation rate $(1.14 \% / h)$. The increase in the postregrowth age of the Massai, Mombasa, and Tanzania grasses increases the acid detergent fiber content and reduces the crude protein content, with a negative effect on the degradation of DM, PB and NDF. The management of these cultivars is indicated at 22 and 34 days postregrowth to obtain forage with better nutritional value. Keywords: Massai grass; chemical composition; in situ degradation

\section{Resumo}

Neste trabalho, objetivou-se avaliar a composição química e a degradação in situ das gramíneas do gênero Panicum Massai, Mombaça e Tanzânia nas idades 22, 34 e 46 dias pós-rebrota. Quantificou-se os teores de 
matéria seca (MS), proteína bruta (PB), fibra em detergente neutro (FDN) e fibra em detergente ácido (FDA). Na avaliação da degradabilidade in situ foram pesadas $4 \mathrm{~g}$ de amostra em sacos de náilon incubados no rúmen de um bovino fistulado, nos tempos 6, 24 e 72 h. Adotou-se delineamento inteiramente casualizado para composição química e em parcela subdividida para degradação in situ, com médias comparadas pelo teste de Tukey a 5\%. Houve aumento nos teores de MS $(+1,69 \%)$ e FDN $(+5,06 \%)(P<0,05)$ das gramíneas nas maiores idades de corte com redução da fração PB. A degradação potencial (DP) da MS, FDN e PB apresentou redução com o aumento da idade das gramíneas, com o aumento no tempo de colonização $(0,69$ h) e a taxa de degradação da FDN $(1,14 \% / h)$. O aumento da idade pós-rebrota das gramíneas Massai, Mombaça, e Tanzânia eleva os teores de fibra em detergente ácido e reduz a proteína bruta, com efeito negativo na degradação da MS, PB e FDN, sendo indicado manejo desses cultivares aos 22 e 34 dias pós-rebrota para se obter forragem com melhor valor nutricional.

Palavras-Chave: Capim massai; Composição química; Degradação in situ.

\section{Introduction}

In the current feeding systems of ruminants on pastures, information is needed regarding the nutritional value and their rates of degradation and utilization in the digestive system, in order to balance the availability of energy and nitrogen in the rumen, maximizing microbial efficiency. However, in tropical regions, due to climatic conditions, forage plants have marked seasonality, with high availability and good nutritional value only in the rainy season, a phenomenon determined mainly by the limitations of light, water availability, and temperature in the dry season ${ }^{(1)}$. Thus, the search for tropical grasses with high productivity in dry matter and adequate nutritional value is a challenge for the production of ruminants.

In Brazil, Panicum maximum grasses are one of the most important forage groups for ruminant production, as they have good nutritional value; tolerance to high temperatures and shading; adequate responses to more intensive cultural treatments; large production of dry matter; easy to establish, even in periods of water deficit, and possible use in intercropping systems $(2,3)$. However, there is little information about their chemical composition and nutritional value.

The cultivar Massai is a hybrid between $P$. maximum and $P$. infestum, and its characteristic is the growth forming clumps with an average height of $60 \mathrm{~cm}$, intermediate tolerance to cold and high resistance to fire, with adaptations to the conditions of low soil fertility ${ }^{(2,5)}$. Panicum maximum CV Mombaça has a high dry matter production, is nutrient-demanding, with good responses when fertilized with nitrogen ${ }^{(5)}$. Tanzania grass (Panicum maximum cv. Tanzania) is an alternative for soil areas with greater fertility, with good resistance to spittlebug and higher production of leaves with adequate nutritional value(15). 
Among the factors related to the management of these forages, the interval between cuts affects both production and quality. Shortening the period between cuts result in lower forage mass, however, increasing the leaf/stem ratio, raising the nutritional value. With advancing age, there is a greater lignification of the cell wall, hindering the action of ruminal microorganisms and resulting in lower degradability of the fiber fraction ${ }^{(26)}$.

In this sense, the assessment of the potentially degradable fractions in the rumen can determine the best time for harvesting the plant, associated with adequate nutritional value. The in-situ degradability technique is adequate to this end and allows quantifying the disappearance of nutrients over time, considering the real conditions of the rumen environment ${ }^{(19,21)}$. The objective of this study was to determine the chemical composition and in situ degradability of grasses of the genus Panicum at three post-regrowth ages.

\section{Material and methods}

The research was carried out at the Animal Sciences Department, Agricultural Sciences Center, Federal University of Piauí, Teresina Campus, at $05^{\circ} 05^{\prime} 21^{\prime \prime} \mathrm{S}, 42^{\circ} 48^{\prime} 07^{\prime \prime} \mathrm{W}$ and 74.4 $m$ altitude, with Aw local climate - according to the Köppen classification, tropical and rainy (megathermal), with dry winter and rainy summer. Chemical analyses were performed at the Animal Nutrition Laboratory (LANA/CCA/UFPI).

The grasses Massai (Panicum maximum Jacq. Cv. Massai), Tanzania (Panicum maximum Jacq. Cv. Tanzania) and Mombasa (Panicum maximum Jacq. Cv. Mombasa) were evaluated, divided into plots, subjected to a standardization cut at $30 \mathrm{~cm}$ from the ground, and NPK fertilization (100-80-50 kg/ha). The plots were irrigated by conventional sprinkler, with sprinklers spaced at 12 meters, with a flow rate of $7.3 \mathrm{~mm} / \mathrm{h}$ and a four-day watering shift, adjusting the water depth to replace the average monthly evapotranspiration of the experimental period $(138.6 \mathrm{~mm})^{(23)}$.

The grasses were harvested at $30 \mathrm{~cm}$ from the ground 22,34 and 46 days after regrowth, identified, weighed and oven dried at $55^{\circ} \mathrm{C}$ for 72 hours for subsequent grinding in a Wiley mill to $1 \mathrm{~mm}$ particles. Samples were analyzed for dry matter (DM), crude protein (CP), mineral matter $(\mathrm{MM})^{(6)}$, neutral detergent fiber (NDF) and acid detergent fiber (ADF) ${ }^{(7)}$.

For analysis of ruminal degradation, 4-g samples were weighed in $12 \times 8 \mathrm{~cm}$ nylon bags with $50 \mu \mathrm{m}$ porosity ${ }^{(8)}$. The bags were incubated for, 6,24 and $72 \mathrm{~h}^{(9)}$ in the rumen of two adult cattle, with an average weight of $450 \mathrm{~kg}$, fistulated, previously fed a diet composed of $80 \%$ forage (chopped wilted elephant grass) and $20 \%$ concentrate (corn, and soybean meal) twice a day ( 8 and 16 hours), with mineral salt and water at will. Four bags were used per treatment in each incubation time, totaling 288 bags, distributed in two animals. The soluble fraction was obtained by immersing bags not incubated in a water bath at $39^{\circ} \mathrm{C}$ for one hour. After removing from the rumen, the bags were immersed in ice water, washed and taken to a forced air oven with at $55^{\circ} \mathrm{C}$ for $72 \mathrm{~h}$ to quantify the contents of $\mathrm{DM}, \mathrm{CP}$ and NDF.

The in situ degradation parameters $(a, b$ and $c$ ) and the potential degradability of DM and $\mathrm{CP}$ were estimated by the model: $\mathrm{PD}=\mathrm{A}-\mathrm{B}^{\mathrm{e}-\mathrm{x} \times \mathrm{t}}$ and effective degradability estimated by the formula $E D=a+[(b c) /(c+k)]$ in the rates of passage of 2.5 and $8 \%{ }^{(10)}$, in order to determine 
the one that best fits the grasses. The NDF degradation parameters were determined according to Mertens \& Loften ${ }^{11}$ : $: \mathrm{Rt}=$ B.e-ct $+\mathrm{I}$, with standardization of fractions, according to Waldo, Smith \& $\operatorname{Cox}^{(12)}$.

The study had a $3 \times 3$ factorial randomized complete block design (three cutting ages $x$ three forages) for chemical composition, and a split plot randomized complete block design for the in situ degradability of DM, CP and NDF, with the treatments representing plots and incubation times, the split plots. PROC MEANS and PROC NLIN of SAS (Statistical Analysis System, version 8) were adopted to obtain means and standard deviation, and degradation parameters, respectively. Tukey's test was applied at 5\% probability to compare the mean values of chemical composition.

\section{Results and discussion}

There was an average increase of $1.69 \%$ in the DM content $(P<0.05)$ of forages when the cut was performed 46 days after regrowth, which is related to the incorporation of fiber constituents in the plant cell structure, associated with DM, with thickening of the wall and increased lignification of the tissues, which is evidenced by the higher content of NDF and ADF in this post-regrowth age (Table 1). The increase in the percentage of NDF and $A D F$, with advancing cutting ages, indicates a reduction in the proportion of nutrients that can be digested by the animal and directly reflects the intake of DM, and rumen microbial metabolism ${ }^{(26)}$.

Table 1. Chemical composition of Panicum grasses harvested at three postregrowth ages

\begin{tabular}{|c|c|c|c|c|}
\hline \multirow[t]{2}{*}{ Grass } & \multirow[t]{2}{*}{ Constituents ${ }^{1}$} & \multicolumn{3}{|c|}{ Cutting age (days) ${ }^{2}$} \\
\hline & & 22 & 34 & 46 \\
\hline \multirow{5}{*}{ Massai } & DM & $91.73^{\mathrm{bA}}$ & $92.25^{\mathrm{bA}}$ & $93.56^{\mathrm{aB}}$ \\
\hline & MM & $9.10^{\mathrm{aC}}$ & $8.57^{\mathrm{aA}}$ & $8.17^{\mathrm{aB}}$ \\
\hline & $\mathrm{CP}$ & $13.18^{\mathrm{aB}}$ & $9.02^{\mathrm{bB}}$ & $7.41^{\mathrm{bB}}$ \\
\hline & ADF & $54.04^{\mathrm{bB}}$ & $55.09^{\mathrm{bB}}$ & $58.63^{\mathrm{aB}}$ \\
\hline & NDF & $87.30^{\mathrm{bA}}$ & $87.51^{\mathrm{bA}}$ & $89.79^{\mathrm{aA}}$ \\
\hline \multirow{5}{*}{ Mombasa } & DM & $91.99^{\mathrm{bA}}$ & $92.06^{\mathrm{bA}}$ & $93.33^{\mathrm{aB}}$ \\
\hline & MM & $11.01^{\mathrm{aA}}$ & $9.13^{\mathrm{bA}}$ & $7.83^{\mathrm{bB}}$ \\
\hline & $\mathrm{CP}$ & $12.55^{\mathrm{aB}}$ & $11.57^{\mathrm{abA}}$ & $9.23^{\mathrm{bAB}}$ \\
\hline & ADF & $53.36^{\mathrm{bA}}$ & $51.88^{\mathrm{bC}}$ & $58.54^{\mathrm{bB}}$ \\
\hline & NDF & $81.75^{\text {bB }}$ & $82.80^{\mathrm{bA}}$ & $85.24^{\mathrm{aB}}$ \\
\hline \multirow{5}{*}{ Tanzania } & $\mathrm{DM}$ & $91.27^{\mathrm{bB}}$ & $92.60^{\mathrm{bA}}$ & $93.75^{\mathrm{aA}}$ \\
\hline & MM & $9.87^{\mathrm{aB}}$ & $9.28^{\mathrm{aA}}$ & $11.17^{\mathrm{aA}}$ \\
\hline & $\mathrm{CP}$ & $12.70^{\mathrm{aB}}$ & $9.36^{\mathrm{bB}}$ & $8.19^{\mathrm{bAB}}$ \\
\hline & ADF & $46.21^{\mathrm{bB}}$ & $46.26^{\mathrm{bD}}$ & $48.94^{\mathrm{aB}}$ \\
\hline & NDF & $84.96^{\mathrm{bA}}$ & $85.16^{\mathrm{bA}}$ & $88.17^{A b}$ \\
\hline
\end{tabular}

'DM: Dry matter; MM: Mineral matter; CP: Crude protein; ADF: Acid detergent fiber; NDF: Neutral detergent fiber.

${ }^{2}$ Mean values followed by different lowercase letters, in the same row, or different uppercase letters, in the same column, are significantly different by Tukey's test at $5 \%$. 
The increased proportion of fiber constituents is associated with the rapid thickening and lignification of the cell wall with advancing plant age, mainly due to the increase in the proportion and thickness of stem in relation to the leaves. This trend is in accordance with the results obtained for grasses of the genus Panicum by Pereira et al.(13), Carvalho et al. ${ }^{(14)}$ and Garcez et al. ${ }^{(26)}$, corroborating the increase in the concentrations of structural carbohydrates with advancing age of the plant for greater support at the vegetative stage. However, variations in the chemical composition of tropical grasses also depend on the type of cultivar, the presence of side tillers, and the light intensity, which does not make the leaf: stem ratio an exclusive determinant of the nutritional value of these species $^{(15)}$.

There was a decrease of $43.78,26.45$ and $31.51 \%$ in CP content at the highest cutting age for the Massai, Mombasa and Tanzania grasses, respectively. The reduction in the contents of this constituent with advancing forage age is associated with the higher complexation of nitrogen compounds with the lignocellulosic fraction of the cell wall. However, even at the highest cutting age, the CP content is above the minimum of $6-8 \%$ in $\mathrm{DM}$, recommended for the maintenance of $8 \mathrm{mg} \mathrm{NH}_{3}-\mathrm{N} \cdot \mathrm{dL}^{-1}$ in the rumen fluid and for the efficient ruminal degradation, with an increase in the production of microbial protein ${ }^{(24) ;}$ these values are equivalent to those obtained for tropical grasses ${ }^{(1,5)}$.

The lower proportion of CP in forages becomes the first limiting factor to intake, as a result of the lower activity of microorganisms in the rumen because of the low availability of nitrogen substrate for synthesis of microbial protein, especially cellulolytic microorganisms, which reduce their growth rate leading to less degradation of fiber fractions, with a consequent reduction in the rate of passage of rumen digesta and negative effects on the digestibility of the other components of the diet ${ }^{(7)}$.

The PD and the potentially degradable fraction of dry matter decreased with advancing cutting age, associated with an increase in the ADF fraction, with low degradability in forages (Table 2). The lower rates of degradation are justified by the thickening of the cell wall and the increase in the proportion of lignin in the leaves. The stem has, in most of its composition, lignified tissues that hinder microbial access to the degradable fraction of the fiber, promoting lower rates of ruminal degradation and limiting the production of energy from glucose present in these polysaccharides ${ }^{(16)}$.

As the grass approaches its physiological maturity and the flowering stage, changes occur in the proportions of its structural components ${ }^{(17)}$, with an increase in cell wall components, associated with the dilution of their content components (organic acids and soluble starch) that have high digestibility ${ }^{(27)}$, negatively impacting the degradation of DM by rumen microorganisms.

There was a high potentially degradable fraction for $\mathrm{CP}$, with a reduction according to advancing cutting age (Table 3), which influences the degradation of the other DM components by making less $\mathrm{N}$ available to the rumen environment. Even with advanced ages, the PD values of this research for forages with up to 34 days after regrowth were higher than those obtained by Guadayo et al. (2019)(18) for cultivars of Panicum maximum (61.47\%) and Brachiaria mutica (64.39\%) at 28 days after regrowth, and by Pinheiro et al. $(2019)^{(19)}$ for Tanzania grass with 24 days of age $(63.3 \%)$. 
Table 2. Ruminal degradability of dry matter of Panicum grasses harvested at three post-regrowth ages

\begin{tabular}{|c|c|c|c|c|c|c|c|c|c|}
\hline \multirow[t]{2}{*}{ Grass } & \multirow[t]{2}{*}{ Cutting age (days) } & \multicolumn{7}{|c|}{ Parameters ${ }^{1}$} & \multirow[t]{2}{*}{$\mathbf{R}^{2}$} \\
\hline & & A & B & c (\%/h') & PD & & ED & & \\
\hline \multirow{4}{*}{ Massai } & & & & & & $2 \%$ & $5 \%$ & $8 \%$ & \\
\hline & 22 & 20.37 & 71.42 & 4.32 & 86.78 & 56.21 & 44.12 & 38.14 & 97.12 \\
\hline & 34 & 18.86 & 52.93 & 4.37 & 67.15 & 51.76 & 41.14 & 36.70 & 92.25 \\
\hline & 46 & 20.15 & 43.29 & 5.17 & 56.81 & 48.21 & 40.43 & 36.19 & 96.55 \\
\hline \multirow{3}{*}{ Mombasa } & 22 & 19.98 & 50.40 & 3.67 & 70.38 & 52.60 & 41.31 & 35.83 & 95.41 \\
\hline & 34 & 21.95 & 36.03 & 4.34 & 67.98 & 50.26 & 43.38 & 39.19 & 94.69 \\
\hline & 46 & 19.64 & 31.15 & 4.33 & 50.79 & 45.29 & 39.92 & 36.41 & 82.95 \\
\hline \multirow{3}{*}{ Tanzania } & 22 & 20.52 & 52.65 & 3.62 & 73.23 & 54.49 & 42.69 & 36.98 & 98.52 \\
\hline & 34 & 21.10 & 46.22 & 3.20 & 67.32 & 49.54 & 39.14 & 34.31 & 99.07 \\
\hline & 46 & 19.76 & 39.33 & 4.67 & 59.09 & 47.30 & 38.75 & 34.26 & 97.74 \\
\hline
\end{tabular}

Soluble fraction $(a)$, potentially degradable $(b)$, degradation rate of fraction $\mathrm{b}(c)$, potential degradation $(\mathrm{PD})$ and effective degradation (ED) determined by the models

$\mathrm{PD}=\mathrm{A}-\mathrm{B} \cdot \mathrm{e}^{-c, t}$ and $\mathrm{ED}=\mathrm{a}+[(\mathrm{b} \times \mathrm{c}) /(\mathrm{c}+\mathrm{k})]^{10}$.

Table 3. Ruminal degradability of crude protein of Panicum grasses harvested at three post-regrowth ages

\begin{tabular}{|c|c|c|c|c|c|c|c|c|c|}
\hline \multirow[t]{2}{*}{ Grass } & \multirow[t]{2}{*}{ Cutting age (days) } & \multicolumn{7}{|c|}{ Parameters ${ }^{1}$} & \multirow[t]{2}{*}{$\mathbf{R}^{2}$} \\
\hline & & A & B & c $\left(\% / h^{1}\right)$ & PD & & ED & & \\
\hline & & & & & & $2 \%$ & $5 \%$ & $8 \%$ & \\
\hline \multirow{3}{*}{ Massai } & 22 & 38.25 & 48.72 & 2.56 & 86.97 & 59.6 & 49.84 & 46.2 & 99.88 \\
\hline & 34 & 35.21 & 36.18 & 2.34 & 75.12 & 51.34 & 47.75 & 41.98 & 96.21 \\
\hline & 46 & 35.10 & 22.12 & 2.92 & 57.22 & 52.26 & 47.94 & 45.36 & 97.12 \\
\hline \multirow{3}{*}{ Mombasa } & 22 & 30.25 & 59.76 & 2.31 & 90.01 & 62.28 & 49.13 & 43.64 & 96.92 \\
\hline & 34 & 32.47 & 44.06 & 2.23 & 76.53 & 55.70 & 46.06 & 42.07 & 94.89 \\
\hline & 46 & 50.15 & 32.56 & 3.83 & 62.71 & 51.54 & 44.27 & 40.69 & 95.22 \\
\hline \multirow{3}{*}{ Tanzania } & 22 & 29.85 & 65.76 & 2.00 & 95.61 & 62.73 & 48.64 & 43.0 & 95.72 \\
\hline & 34 & 26.68 & 59.98 & 1.53 & 89.83 & 53.71 & 41.02 & 36.31 & 98.24 \\
\hline & 46 & 26.81 & 52.48 & 2.49 & 79.81 & 49.76 & 39.40 & 35.59 & 89.73 \\
\hline
\end{tabular}

${ }^{1}$ Soluble fraction $(a)$, potentially degradable $(b)$, degradation rate of fraction $\mathrm{b}(c)$, potential degradation (PD) and effective degradation (ED) determined by the models $P D=A-B \cdot e^{-c . t}$ and $E D=a+[(b \times c) /(c+k)]^{10}$.

Reductions in the degradation rate of nitrogen fractions from 34 days can reduce the amount of ammonia nitrogen available to rumen microorganisms, which use it for the synthesis of amino acids, cell structures, and growth ${ }^{(25)}$, which negatively impacts the 
DM degradability (Table 2). In tropical grasses, a reduction in the protein degradation rate is expected with advancing age, associated with factors such as climate, water availability, and temperature, with the incorporation of this fraction in the less soluble components of the forage ${ }^{(1,13)}$.

The level of rumen degradability of CP can be variable between different forage species, which determines the availability of ammonia nitrogen in the rumen, and the proportion of amino acids from the diet and microbial protein, that reach the intestine, which are directed to tissue protein synthesis ${ }^{(25)}$. The concentration of crude protein is higher at the vegetative stages of forages and decline at the flowering stage, which may vary depending on differences between species, initial level of protein in the plant, stem and leaf proportions, content of fiber components in the cell wall and ambient temperature ${ }^{(15,21)}$.

There was an increase in the undegradable NDF fraction (Ip) with advancing cutting age of the grasses, which may justify the negative variations in their potential and effective DM degradation, since the NDF accounts for more than $70 \%$ of its composition (Table 4). Lower NDF degradation in tropical grasses with advanced regrowth ages is common in tropical regions, since they quickly reach phenological maturity, incorporating support structures represented by lignified fiber ${ }^{(20)}$.

Table 4. Ruminal degradability of neutral detergent fiber of Panicum grasses harvested at three post-regrowth ages.

\begin{tabular}{|c|c|c|c|c|c|c|}
\hline \multirow[t]{2}{*}{ Grass } & \multirow[t]{2}{*}{ Cutting age (days) } & \multicolumn{4}{|c|}{ Parameters $^{1}$} & \multirow[t]{2}{*}{$R^{2}$} \\
\hline & & Bp & Ip & Lag & k (\%/h) & \\
\hline & 22 & 72.75 & 27.25 & 4.06 & 4.50 & 99.16 \\
\hline \multirow[t]{2}{*}{ Massai } & 34 & 66.09 & 33.91 & 4.89 & 3.60 & 98.96 \\
\hline & 46 & 64.66 & 35.34 & 4.27 & 1.90 & 99.24 \\
\hline \multirow{3}{*}{ Mombasa } & 22 & 70.02 & 29.98 & 4.65 & 3.02 & 99.14 \\
\hline & 34 & 62.14 & 37.86 & 4.81 & 2.70 & 96.19 \\
\hline & 46 & 51.07 & 48.93 & 4.85 & 2.49 & 95.16 \\
\hline \multirow{3}{*}{ Tanzania } & 22 & 74.80 & 25.20 & 4.42 & 4.10 & 89.94 \\
\hline & 34 & 67.91 & 32.09 & 4.94 & 4.04 & 88.91 \\
\hline & 46 & 66.83 & 33.17 & 4.76 & 2.24 & 94.96 \\
\hline
\end{tabular}

'Standardized potentially degradable fraction (Bp), standardized undegradable fraction (Ip), colonization time (lag), degradation rate ( $k$ ) obtained by the models $R t=B^{e \cdot c x t}+I^{(11)}, B p=B /(B+I) \times 100^{(12)}$ and $I p=I /(B+I) \times 100^{(12)}$.

The results obtained for the degradable NDF fraction at the lowest cutting ages were, on average, $12 \%$ lower than reported by Costa et al. ${ }^{(4)}$ for Mombasa grass $(80.41 \%)$ and Tifton-85 (80.06\%) with 21 days after regrowth. The composition of the cell wall varies according to the forage species, the soil, the ambient temperature, the resilience of the 
plant, and its phenological characteristics, the latter is important in tropical grasses that reach the maturity earlier, and may present reductions in degradation of fiber fractions in shorter intervals.

The NDF colonization time (lag) $(0.69 \mathrm{~h})$ increased, leading to a decline in the rate of passage $(1.14 \% / h)$ at the highest cutting ages. The colonization time of the fiber fraction represents the time between the start of incubation and ruminal degradation and is associated with the ability of rumen microorganisms to attach to the particles ${ }^{(21)}$, increasing when there is a greater proportion of lignified cell wall in the forage, makes it difficult for microorganisms to adhere. Associated with this effect, there is a reduction in ruminal degradation of the fiber fraction, as observed in this study, which can affect the ruminal passage rate and negatively imply the intake of DM.

As for the colonization time (lag), the average values were high and higher than those found for grasses, with an increase with advancing age of forages. This effect may be associated with the dissolution of soluble carbohydrates and protein components that, although with a lower proportion in species, showed greater availability for microbial degradation (Tables 1 and 2) at earlier ages, consequently, with greater competition for these substrates, affecting the lag time of cell wall by fibrolytic bacteria(22).

NDF degradability and the rate of passage of the digesta are directly associated with forage intake, which also depends on the rate of degradation of the nutritional components in the diet. Leaves and stems have different rumen retention times, due to the greater resistance to degradation of stems, which result in changes in food intake, with a decrease in consumption with increasing plant maturity, depending on the chemical characteristics of the cell wall that becomes thicker and lignified; a determining factor in the digestive process of ruminants ${ }^{(20)}$.

\section{Conclusions}

The increase in the post-regrowth age in Massai, Mombasa and Tanzania grasses increases the acid detergent fiber content and reduces the crude protein content, with a negative effect on the degradation of DM, PB and NDF. The management of these cultivars is indicated at 22 and 34 days post-regrowth to obtain forage with better nutritional value.

\section{References}

1. Mochel Filho WJE, Carneiro MSS, Andrade AC, Pereira ES, Andrade AP, Candido MJDS, Magalhães JA, Braz HN, Santos FJ, Costa NL. Produtividade e composição bromatológica de Panicum maximum cV. Mombaça sob irrigação e adubação azotada. Rev. Ciênc. Agrár., 2016, 39(1): 81-88. Disponível em: http:// dx.doi.org/10.19084/RCA14154.

2. Silva JL, Ribeiro KG, Herculano BM, Pereira OG, Pereira RC, Soares LFP. Massa de forragem e características estruturais e bromatológicas de cultivares de Brachiaria e Panicum. Cienc. anim. bras., 2016, (17)3: 342-348. Disponível em: http://dx.doi.org/10.1590/1089-6891v17i332914. 
Ruminal degradation of Panicum grasses in three post-regrowth ages

Garcez B.S. et al.

3. Paciullo DSC, Gomide CAM, Castro CRT, Mauricio RM, Fernandes PB, Morenz MJF. Morphogenesis, biomass and nutritive value of Panicum maximum under different shade levels and fertilizer nitrogen rates. 2016, 72(3): 590-600. Disponível em: https://doi.org/10.1111/gfs.12264.

4. Costa FAA, Fernandes LB, Garcia VP, Soares WVB, Franzolin R. Degradabilidade de gramíneas, fermentação e protozoários no rúmen de bovinos em dietas com diferentes aditivos. Rev. Bras. Saúde Prod. Anim., 2017, 18(2): 269-281. Disponível em: http://dx.doi.org/10.1590/s1519-99402017000200006.

5. Galindo FS, Buzetti S, Teixeira Filho MCM, Dupas E, Carvalho FC. Manejo da adubação nitrogenada no capim-mombaça em função de fontes e doses de nitrogênio. Rev. Ciênc. Agrár. 2018, 41(4): 900-913. Disponível em: http://dx.doi.org/10.19084/RCA18131.

6. ASSOCIATION OF ANALYTICAL COMMUNITIES - AOAC International. Official methods of analysis of AOAC international, 19 ${ }^{\text {th }}$.ed., Gaithersburg, MD, USA: Association of Analytical Communities, 2012. 2610p.

7. Van Soest PJ, Robertson JB, Lewis BA. Methods for Dietary Fiber, Neutral Detergent Fiber, and Nonstarch Polysaccharides in Relation to Animal Nutrition. J. of Dair. Sci., 1991, 74 (10): 3583-97. Disponível em: http://dx.doi.org/10.3168/jds.S0022-0302(91)78551-2

8. Campos MM, Borges ALCC, Lopes FCF, Pancoti CG; Reis e Silva R. Degradabilidade in situ da cana-deaçúcar tratada ou não com óxido de cálcio, em novilhas leiteiras Holandês x Gir. Arq. Bras. Med. Vet. Zootec. 2011, 63(6): 1487-1492. Disponível em: http://dx.doi.org/10.1590/S0102-09352011000600028.

9. NATIONAL RESEARCH COUNCIL. NRC. Nutrient requirements of dairy cattle. $7^{\text {th }}$ rev. ed. Washington, D.C.: National Academy Press, 2001. 381 p.

10. Ørskov DR, Mcdonald I. The estimation of protein degradability in the rumen from incubation measurements weighted according to rate of passage. Jour. Agric. Sci. 1979, 92 (12): 499-503. Disponível em: http://dx.doi.org/10.1017/S0021859600063048.

11. Mertens DR, Loften JR. The effect of starch on forage fiber digestion kinetics in vitro. Journ. Dayr. Sci. 1980, 63 (21): 1437-1446. Disponível em: www.ncbi.nlm.nih.gov/pubmed/6253541.

12. Waldo DR, Smith LW, Cox LE. Model of cellulose disappearance from the rumen. Journ. Dayr. Sci. 1972, 55(12): 125-129. Disponível em: https://doi.org/10.3168/jds.50022-0302(72)85442-0

13. Pereira GAC, Lima RL, Silva JA, Galati RL, Zervoudakis JT, Abreu JG, Jesus LP, Santos VAC, Ceni I, Cabral LC. Dry matter production and chemical composition of Massai grass submitted to nitrogen rates and cutting heights. Semina: Ciênc. Agrár. 2016, 37(4): 2487-2498. Disponível em: http://dx.doi. org/10.5433/1679-0359.2016v37n4Supl1p2487.

14. Carvalho ALS, Martuscello JA, Almeida OG, Braz TGS, Cunha DNFV, Jank L. Production and quality of Mombaça grass forage under diferente residual heights. Acta Sci. Anim. Sci. 2017, 39(2): 143-148. Disponível em: http://dx.doi.org/10.4025/actascianimsci.v39i2.34599.

15. Poczynec M, Neumann M, Horst EH, Leão GFM, Poczynec M, Ueno RK. Capacidade produtiva e qualidade nutricional de gramíneas perenes submetidas a sistema contínuo de cortes. Arq. Bras. Med. Vet. Zootec. 2016, 68(3): 785-794. Disponível em: http://dx.doi.org/10.1590/1678-4162-8768

16. Oliveira ER, Monção FP, Gabriel AMA, Silva LHX, Carbonari VMS, Pedroso FW, Pereira TL, Nascimento FA. Valor nutricional do colmo de gramíneas tropicais. Sci. Agrar. Parana., 2016, 15(3): 256-264. Disponível em: http://dx.doi.org/10.18188/sap.v15i3.13558.

17. Monção FP, Oliveira ER, Gabriel AMA, Nascimento FA, Pedroso FW, Freitas LL. Nutritional parameters of leaf blade from different tropical forages. 2016. Scient. Agrar. 15(2): 185-193. Disponível em: http:// dx.doi.org/10.18188/1983-1471/sap.v15n2p185-193.

18. Guadayo GF, Rayos AA, Merca FE, Tandang AG, Loresco MM, Angeles AA. Prediction of In Situ Ruminal 
Ruminal degradation of Panicum grasses in three post-regrowth ages

Garcez B.S. et al.

Degradability of Forages in Buffaloes Using the In Vitro Gas Production Technique. 2019. Trop. J. Anim. Sci., 42(2): 128-136. Disponível em: https://doi.org/10.5398/tasj.2019.42.2.128.

19. Pinheiro JK, Ferreira RR, Gonzaga NETO S, Signoretti RD, Henriques LT, Oliveira JS. Dynamics of degradation of high-quality tropical forage according to levels of nitrogen supplementation. 2019. Trop. Anim. Health Prod., 15(2): 198-2012. Disponível em: https://doi.org/10.1007/s11250-019-02136-1.

20. Muniz EB, Mizubuiti IY, Pereira ES, Pimentel PG, Ribeiro ELA, Pinto AP. Cinética ruminal da fração fibrosa de volumosos para ruminantes. Rev. Ciênc. Agron. 2012, (43)3: 604-610. Disponível em: http:// www.ccarevista.ufc.br/seer/index.php/ccarevista/article/view/1456/724.

21. Smith WB, Foster JL, McCuistion KC, Tedeschi LO, Rouquette FM. In situ Degradation Patterns of 'Tifton 85' Bermudagrass with Dried Distillers' Grains Supplementation. Crop Sci. 2017, 57(3): 173-185. Disponível em: http://dx.doi.org/10.2135/cropsci2016.12.0981.

22. Detmann E, Queiroz AC; Zorki A, Mantovani HC, Bayão GFV, Gomes MPC. Degradação in vitro da fibra em detergente neutro de forragem tropical de baixa qualidade em função da suplementação com proteína verdadeira e/ou nitrogênio não-proteico. R. Bras. Zootec. 2011, 40(6): 1272-1279. Disponível em: http://dx.doi.org/10.1590/S1516-35982011000600016.

23. Gomes ANN, Andrade Junior AS, Medeiros RM. Evapotranspiração de referência mensal para o Estado do Piauí. Rev. Bras. Eng. Agríc. Ambient. 2005, 9(4): 560-564. Disponível em: http://dx.doi.org/10.1590/ S1415-43662005000400019.

24. Castro-Montoya J, Westreicher-Kristen E, Diaby AHM, Susenbeth A, Dickhoefer U. In vitro microbial protein synthesis, ruminal degradation and post-ruminal digestibility of crude protein of dairy rations containing Quebracho tannin extract. J Anim Physiol Anim Nutr. 2017, 102(1): 1-10. Disponível em: http:// dx.doi.org/10.1111/jpn.12704.

25. Dentinho MT, Paulos K, Portugual PV, Moreira OC, Silva JS, Bessa RJB. Proteolysis and in situ ruminal degradation of lucerne ensiled with Cistus ladanifer tannins. 2019. Grass Forage Sci. 74(8): 78-85. Disponível em: http://dx.doi.org/10.1111/gfs.12394.

26. Garcez BS, Alves AA, Araujo DLC, Lacerda MSB, Sousa LGS, Carvalho LF. Degradabilidade ruminal do capim Colonião (Panicum maximum jacq. Cv. Colonião) em três idades pós-rebrota. 2016, Acta Vet Bras. 10(2): 130-134. Disponível em: https://doi.org/10.21708/avb.2016.10.2.5513.

27. Andrade WR, Sales ECJ, Rigueira JPS, Gomes VGM, Rufino LD, Pires DAA, Moura MMA, David GSS, Silva MCA, Jesus MO, Barroso AJMA, Alencar JM, Monção FP. Structural characteristics, nutritional value of Tifton 85 grass under nitrogen doses at different ages of regrowth in the semiarid. 2018, Rev. Ciênc. Agrár. 41(4): 893-899. Disponível em: https://doi.org/10.19084/RCA17293. 